\title{
The changes in antigenic components of Vibrio cholerae strains isolated in Vietnam
}

\author{
Sụ biến đổi thành phần kháng nguyên của các chủng Vibrio cholerae phân lập \\ ơ Việt Nam
}

Research article

Ha, Thi Quyen ${ }^{1 *}$; Dinh, Duy Khang ${ }^{2}$

${ }^{1}$ University of Engineering and Technology, Vietnam National University, 144 Xuan Thuy, Cau Giay, Hanoi, Vietnam;

${ }^{2}$ Institute of Biotechnology, Vietnam Academy of Science and Technology, 18 Hoang Quoc Viet, Hanoi, Vietnam

\begin{abstract}
Whole cells of Vibrio cholerare serotype Inaba and serotype Ogawa (strains I389 and O395) were injected into rabbits to obtain antiserum. The antiserums were used for immune reaction with antigenic components of 25 strains of V.cholerae isolated from five provinces of Vietnam and the two standard strains I389 and O395 by Western-blot technique. Analysis of immune hybrid results showed that there were 11 antigenic components with molecular weights approximately $79 \mathrm{kDa}$, $62 \mathrm{kDa}, 52 \mathrm{kDa}, 45 \mathrm{kDa}, 42 \mathrm{kDa}, 38 \mathrm{kDa}, 35 \mathrm{kDa}, 31 \mathrm{kDa}, 26 \mathrm{kDa}, 23 \mathrm{kDa}$ and $20 \mathrm{kDa}$. In which the antigens of $45 \mathrm{kDa}, 42 \mathrm{kDa}, 31 \mathrm{kDa}$ and $20 \mathrm{kDa}$ were similar to OmpT, OmpS, Omp-31kDa and TcpA that have been considered as vaccine-candidate antigens. Among 25 V.cholerae strains, there were 6 antigenic components in common including $79 \mathrm{kDa}, 62 \mathrm{kDa}, 45 \mathrm{kDa}, 35 \mathrm{kDa}, 31 \mathrm{kDa}$ and $20 \mathrm{kDa}$. $23 / 25$ strains contained $42 \mathrm{kDa}$ antigen; $5 / 25$ strains contained $38 \mathrm{kDa}$ and $23 \mathrm{kDa}$ antigens; $11 / 25$ had $26 \mathrm{kDa}$ antigen. In addition, $7 / 25$ strains contained antigens identical to V.cholerae I389 serotype Inaba; 6/25 strains contained antigens of I389 and O395; 12/25 strains had changes of antigenic components. These changes were actually the lack of antigens, not appearing new antigens. These results are considered as basis for researches about immune response and prevention of cholera disease.
\end{abstract}

Toàn bộ tế bào của các chủng Vibrio cholerare typ huyết thanh Inaba và typ huyết thanh Ogawa (chủng I389 và O395) được sủ dụng để gây miễn dịch trên thỏ để thu kháng huyết thanh. Các kháng huyết thanh được dùng để thực hiện phản ứng miễn dịch với các thành phần kháng nguyên của 25 chủng V.cholerae phân lập tù 5 tỉnh thành của Việt Nam và hai chủng chuẩn 1389 và 0395 bằng kỹ thuật Western-blot. Phân tích kết quả lai miễn dịch cho thấy, có tổng số 11 thành phần kháng nguyên có kích thuớc khoảng 79kDa, 62kDa, 52kDa, 45kDa, 42kDa, 38kDa, 35kDa, $31 \mathrm{kDa}, 26 \mathrm{kDa}, 23 \mathrm{kDa}$ và $20 \mathrm{kDa}$. Các kháng nguyên này chủ yếu là các protein màng ngoài (Omp) và kháng nguyên lông (TcpA). Trong đó các kháng nguyên 45kDa, 42kDa, 31kDa và $20 k D a$ trùng với các kháng nguyên OmpS, OmpT, Omp-31kDa và TcpA được xem là nhũng kháng nguyên dư tuyển vacxin tả. Có 6 kháng nguyên chung giũa 25 chủng với kích thuớc $79 k D a$, $62 k D a, 45 k D a, 35 k D a, 31 k D a$ và $20 k D a$. 7/25 chủng có các kháng nguyên giống với kháng nguyên của chủng $V$. cholerae I389 typ huyết thanh Inaba; 6/25 chủng có các kháng nguyên giống vói kháng nguyên của cả hai chủng V.cholerae 1389 và O395; 12/25 chủng có sụ biến đổi thành phần kháng nguyên. Tuy nhiên, sụ biến đổi này thực chất là sụ thiếu hưt chư không phải là sư xuất hiện các thành phần kháng nguyên mói. Các kết quả nghiên cứu này có thể được xem là nền tảng ban đầu cho các nghiên cứu về miễn dịch và dụ phòng bệnh tả.

Keywords: Vibrio cholerae serotype Inaba, Vibrio cholerae serotype Ogawa, antiserum, antigens of Vibrio cholerae, outer membrane protein, TcpA

\section{Introduction}

Vibrio cholerae is the etiologic agent for the diarrheal disease (cholera disease) in many areas of Asia, Africa and Latin America (Kenneth Todar, 2002). V.cholerae settled on mucosa membrane of small intestine, but did not invade into the intestinal epithelial cells. However, the vaccine trials showed that antibodies producing in cholera 
immune responses are present in both of the serum and intestine (Forrest B.D., 1992).

According to previous studies, V.cholerae has a variety of antigens causing immune responses such as $\mathrm{O}$ antigen, $\mathrm{B}$ subunit of cholera toxin, toxin co-regulated pili (Tcp), mannose sensitive haemagglutinin factor (MSHA) and outer membrane proteins (Omps) (Richardson K. et al., 1989; Tacket C.O. et al., 1998). Particularly, the O antigen is capable to cause immune responses against bacteria, while sub-section B subunit is capable to cause immune responses against cholera-toxin (Taylor D.N. et al., 2000). Both of them are co-effects causing immune responses against cholera. The remaining antigens such as Tcp, MSHA and Omps play an important role for immune response against settlement of V.cholerae in the small intestine.
Beside researches on detection of antigens for development of vaccines, researches on antigenic components of V.cholerae strains isolated in different areas are necessary to control cholera disease. Thus, the purpose of this paper is research on changes in the antigenic components of V.cholerae strains isolated in different geographical areas of Vietnam to provide information for molecular epidemiological surveillance and cholera prevention.

\section{Materials and methods}

\subsection{Materials}

V.cholerae strains were isolated in the different areas of Vietnam. After that they were stored and managed by Institute of Hygiene and Epidemiology, Ministry of Health, Vietnam.

Table 1. Vibrio cholerae strains and isolated places in Vietnam

\begin{tabular}{cccccccc}
\hline Strains & $\begin{array}{c}\text { Isolated } \\
\text { places }\end{array}$ & Strains & $\begin{array}{c}\text { Isolated } \\
\text { places }\end{array}$ & Strains & $\begin{array}{c}\text { Isolated } \\
\text { places }\end{array}$ & Strains & Isolated places \\
\hline $1 \mathrm{AG}$ & An Giang & $8 \mathrm{HN}$ & Hanoi & $15 \mathrm{HN}$ & Hanoi & $22 \mathrm{HP}$ & Hai Phong \\
$2 \mathrm{AG}$ & An Giang & $9 \mathrm{HN}$ & Hanoi & $16 \mathrm{QN}$ & Quang Ninh & $23 \mathrm{HP}$ & Hai Phong \\
$3 \mathrm{AG}$ & An Giang & $10 \mathrm{HN}$ & Hanoi & $17 \mathrm{HN}$ & Hanoi & $24 \mathrm{HP}$ & Hai Phong \\
$4 \mathrm{CM}$ & $\mathrm{Ca} \mathrm{Mau}$ & $11 \mathrm{HP}$ & Hai Phong & $18 \mathrm{HN}$ & Hanoi & $25 \mathrm{HP}$ & Hai Phong \\
$5 \mathrm{HN}$ & Hanoi & $12 \mathrm{AG}$ & An Giang & $19 \mathrm{HN}$ & Hanoi & I389 & Standard strain \\
$6 \mathrm{HN}$ & Hanoi & $13 \mathrm{HP}$ & Hai Phong & $20 \mathrm{HN}$ & Hanoi & O395 & Standard strain \\
$7 \mathrm{HN}$ & Hanoi & $14 \mathrm{HP}$ & Hai Phong & $21 \mathrm{HN}$ & Hanoi & & \\
\hline
\end{tabular}

\subsection{Methods}

\subsubsection{Bacterial culturing}

V.cholerae were cultured in APW media (peptone 10g/1, $\mathrm{NaCl} 10 \mathrm{~g} / \mathrm{l})$. Time for culturing was from 16 to 24 hours at $37^{\circ} \mathrm{C}$.

\subsubsection{Antiserums producing}

Steps for producing antibodies in rabbits: (1) $1 \mathrm{ml}$ of V.cholerae cells serotypes Inaba and Ogawa $\left(\mathrm{OD}_{600 \mathrm{~nm}}=\right.$ 1) was inactivated by heat, and injected directly to rabbits; (2) injection again after 5, 14 and 30 days to exploit primary immune responses (production of primary antibodies) and secondary immune responses (production of antibodies quickly and much); (3) After 10 days since last injection, blood of rabbits was obtained, incubated for 2 hours at $37^{\circ} \mathrm{C}$, held for 2 hours at $40^{\circ} \mathrm{C}$; (4) centrifuging blood of rabbits for $10 \mathrm{~min}$, collecting serum, preserving for immune hybrid.

\subsubsection{Checking antigenic components of $V$. cholerae strains by Western-blot}

Main steps of Western-blot: (1) denaturing cultured bacterial liquids at $100^{\circ} \mathrm{C}$ for 10 minutes; (2) analyzing proteins of bacteria by SDS-PAGE electrophoresis; (3) transferring proteins to PVDF membrane (Polyvinylidene fluoride); (4) dyeing PVDF membrane with $0.1 \%$ ponceau solution; (5) coating PVDF membrane with 5\% skim milk at $40^{\circ} \mathrm{C}$ overnight to cover positions of PVDF membrane without proteins; (6) adding Inaba antiserum and Ogawa antiserum (diluted with 5\% skim milk) to coat PVDF membrane for 2 hours. (7) coating PVDF membrane with anti-rabbit antibody attached horse-radish peroxidase (diluted with 5\% skim milk) for 2 hours; (8) washing PVDF membrane with TTBS and TBS each 5 minutes, repeating two times; (9) adding solution containing $5 \mathrm{ml}$ methanol $+15 \mathrm{mg}$ 4-chloronaphthol $+25 \mathrm{ml}$ TBS $+15 \mu 1 \mathrm{H}_{2} \mathrm{O}_{2} 30 \%$ for detecting colour.

\section{Results and discussions}

\subsection{The antigenic components of V.cholerae I389 serotype Inaba and 0395 serotype Og- awa}

Inaba antiserum and Ogawa antiserum were used to check antigenic components of V.cholerae serotype Inaba and serotype Ogawa by immune hybrid (Figure 1).

The antigenic components of V.cholerae I389 contained 10 bands with molecular weights approximately $79 \mathrm{kDa}$, $62 \mathrm{kDa}, 45 \mathrm{kDa}, 42 \mathrm{kDa}, 38 \mathrm{kDa}, 35 \mathrm{kDa}, 31 \mathrm{kDa}, 26 \mathrm{kDa}$, $23 \mathrm{kDa}$ and $20 \mathrm{kDa}$. And the antigenic components of V.cholerae 0395 contained 8 bands with molecular weights approximately $79 \mathrm{kDa}, 62 \mathrm{kDa}, 52 \mathrm{kDa}, 42 \mathrm{kDa}$, $35 \mathrm{kDa}, 26 \mathrm{kDa}, 23 \mathrm{kDa}$ and $20 \mathrm{kDa}$. So there were 7 antigens in common between $V$.cholerae serotype Inaba and serotype Ogawa. The difference between two serotypes mainly based on lacking of three bands (sizes of $31 \mathrm{kDa}$, 
$38 \mathrm{kDa}$ and $45 \mathrm{kDa}$ ) and appearing one more band (size $52 \mathrm{kDa}$ ) of serotype Ogawa.

The antigen with size $20 \mathrm{kDa}$ was similar to TcpA antigen. TcpA is usually used as a component in vaccines against cholera (Asaduzzman M. et al., 2004; Du Yan et al., 2004).

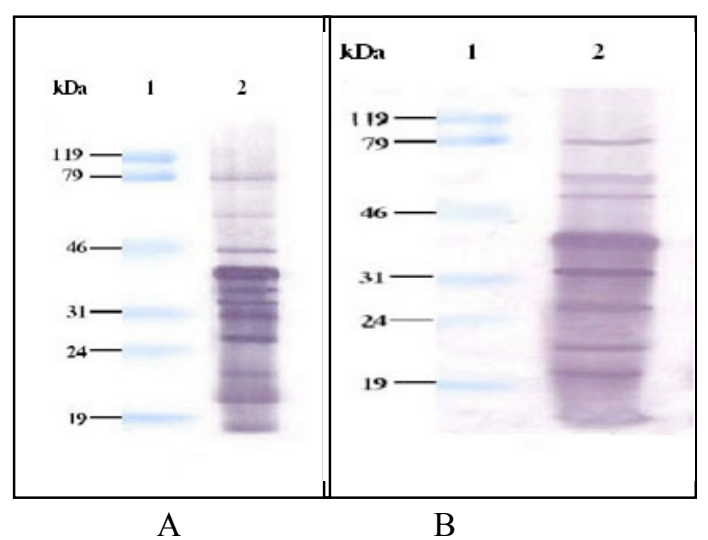

Figure 1. (A) Antigenic components of V.cholerae serotype Inaba (I389 strain). (B) Antigeinc components of V.cholerae serotype Ogawba (O395 strain); A1, B1: protein marker

The $23 \mathrm{kDa}$ antigen was same to a heat shock protein -Hsp and the antigen with size $26 \mathrm{kDa}$ was similar to OmpV-an outer membrane antigen. It is also a heat induced-protein. Both of these antigens were described by Sahu G.K. et al. (1994).

The antigen with $31 \mathrm{kDa}$ size was an outer membrane protein $(\mathrm{Omp}-31 \mathrm{kDa})$ that was researched by Kuma S. et al. (2001). The $35 \mathrm{kDa}$ antigen was said to be OmpA that was easy to be changed by heat (Simonet V.C. et al., 2003). The $38 \mathrm{kDa}$ antigen was similar to OmpU, an outer membrane protein with pore-forming ability mentioned by Sperandio V. et al. (1995) and Simonet V.C. et al. (2003). The antigens with $42 \mathrm{kDa}$ and $45 \mathrm{kDa}$ sizes were described like to OmpT with pore-forming ability (Simonet V.C. et al., 2003; Stewart-Tull D.E. et al., 2004) and OmpS (Stewart-Tull D.E. et al, 2004). Both of these antigens have proteinases activity.
Kumar S. et al. (2001) mentioned and described the $52 \mathrm{kDa}$ antigen as a proteinase, named Omp-52kDa. The antigen with $62 \mathrm{kDa}$ size was similar to a Hsp of the outer membrane. It is also a protein with proteinase activity (Sahu G.K. et al., 1994). The antigens of $26 \mathrm{kDa}, 31 \mathrm{kDa}$, $42 \mathrm{kDa}$ and $45 \mathrm{kDa}$ have been considered as vaccinecandidate antigens for development of vaccines against cholera (Stewart-Tull D.E. et al, 2004).

Growing conditions are major factors affecting expression of antigens of V.cholerae (such as Omp, Tcp and cholera toxin). The expression of the antigens is controlled by a regulatory protein - ToxR (same to regulatory mechanism for expression of cholera toxin). Activity of ToxR is controlled by environmental signals. According to Richardson et al. (1989), the antigens with higher molecular weights $(>84 \mathrm{kDa})$ of V.cholerae only appear when $V$. cholerae grows in in-vivo condition. In our experiments, V.cholerae strains were cultured in in-vitro condition so that may be why antigens with molecular weights less than or equal to $79 \mathrm{kDa}$ were expressed.

\subsection{Changes of the antigenic components of V.cholerae strains}

Inaba and Ogawa antiserums were used for immune hybrid with antigens of 25 V.cholerae strains isolated in some provinces of Vietnam and two standard strains (I389 and O395). Western-blot results are showed in Figure 2 and Figure 3. The statistics of antigenic components of V.cholerae strains are indicated in Table 2 and Table 3 .

In the Figure 2 and Table 2, the antigenic components of 25 V.cholerae strains were divided into five groups. The group of 13 strains $(5-6 \mathrm{HN}, 8 \mathrm{HN}, 17-21 \mathrm{HN}, 22-25 \mathrm{HP}$, and $1 \mathrm{AG}$ ) had 10 antigens similar to I389; the group of $3 \mathrm{AG}$ and $7 \mathrm{HN}$ strains lacked 4 antigens $(42 \mathrm{kDa}, 38 \mathrm{kDa}$, $26 \mathrm{kDa}$ and $23 \mathrm{kDa}$ ); the group of $2 \mathrm{AG}$ and $4 \mathrm{CM}$ strains lacked 3 antigens $(38 \mathrm{kDa}, 26 \mathrm{kDa}$ and $23 \mathrm{kDa})$; the group of $11 \mathrm{HP}$ strain lacked 2 antigens $(38 \mathrm{kDa}$ and $23 \mathrm{kDa})$; and the group of $9 \mathrm{HN}, 10 \mathrm{HN}, 12 \mathrm{AG}, 13 \mathrm{HP}, 14 \mathrm{HP}, 15 \mathrm{HN}$ and $16 \mathrm{QN}$ strains lacked $26 \mathrm{kDa}$ antigen.

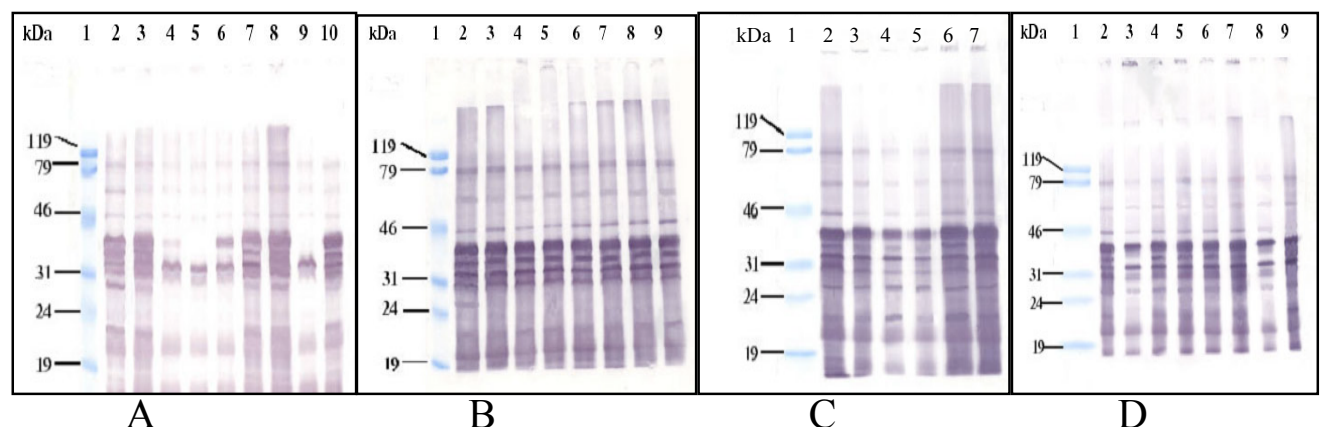

Figure 2. Western-blot of Inaba antiserum and V.cholerae strains (see tab. 1) (A) strains 1-8; (B) strains 9-10; 12-16; (C) strains 17-21; (D) strains 11, 22-25 and 0395. (Protein marker: A1, B1, C1, D1; I389: A2, B2, C2, D2; O395: D9; 11HP:D3, D8) 
In the Figure 3 and Table 3, the antigenic components of $25 \mathrm{~V}$. cholerae strains were divided into six groups. The group of $1 \mathrm{AG}, 5 \mathrm{HN}, 6 \mathrm{HN}, 8 \mathrm{HN}, 20 \mathrm{HN}$ and $21 \mathrm{HN}$ strains contained antigens similar to $\mathrm{O} 395$; the group of $17 \mathrm{HN}$, $18 \mathrm{HN}, 19 \mathrm{HN}, 22 \mathrm{HP}, 23 \mathrm{HP}, 24 \mathrm{HP}$ and $25 \mathrm{HP}$ strains lacked $52 \mathrm{kDa}$ antigen; the group of $9 \mathrm{HN}, 10 \mathrm{HN}, 12 \mathrm{AG}$, $13 \mathrm{HP}, 14 \mathrm{HP}, 15 \mathrm{HN}$ and $16 \mathrm{QN}$ lacked $26 \mathrm{kDa}$ antigen; the group of $11 \mathrm{HP}$ strain lacked $23 \mathrm{kDa}$ antigen; the group of $2 \mathrm{AG}$ and $4 \mathrm{CM}$ strains lacked $26 \mathrm{kDa}$ and $23 \mathrm{kDa}$ antigens; and the group of $3 \mathrm{AG}$ and $7 \mathrm{HN}$ strains lacked $42 \mathrm{kDa}$ and $26 \mathrm{kDa}$ antigens.

Table 2. The difference of the antigenic components of V.cholerae strains (using Inaba antiserum in Western-blot)

\begin{tabular}{ccccccccccccc}
\hline Strains & \multicolumn{1}{c}{ Antigens Size $(\mathrm{kDa})$} & & & \\
\cline { 2 - 9 } & 79 & 62 & 45 & 42 & 38 & 35 & 31 & 26 & 23 & 20 \\
\hline $\mathrm{I} 389$ & + & + & + & + & + & + & + & + & + & + \\
$1 \mathrm{AG}$ & + & + & + & + & + & + & + & + & + & + \\
$2 \mathrm{AG}$ & + & + & + & + & - & + & + & - & - & + \\
$3 \mathrm{AG}$ & + & + & + & - & - & + & + & - & - & + \\
$4 \mathrm{CM}$ & + & + & + & + & - & + & + & - & - & + \\
$5 \mathrm{HN}$ & + & + & + & + & + & + & + & + & + & + \\
$6 \mathrm{HN}$ & + & + & + & + & + & + & + & + & + & + \\
$7 \mathrm{HN}$ & + & + & + & - & - & + & + & - & - & + \\
$8 \mathrm{HN}$ & + & + & + & + & + & + & + & + & + & + \\
$9 \mathrm{HN}$ & + & + & + & + & + & + & + & - & + & + \\
$10 \mathrm{HN}$ & + & + & + & + & + & + & + & - & + & + \\
$11 \mathrm{HP}$ & + & + & + & + & - & + & + & + & - & + \\
$12 \mathrm{AG}$ & + & + & + & + & + & + & + & - & + & + \\
$13 \mathrm{HP}$ & + & + & + & + & + & + & + & - & + & + \\
$14 \mathrm{HP}$ & + & + & + & + & + & + & + & - & + & + \\
$15 \mathrm{HN}$ & + & + & + & + & + & + & + & - & + & + \\
$16 \mathrm{QN}$ & + & + & + & + & + & + & + & - & + & + \\
$17 \mathrm{HN}$ & + & + & + & + & + & + & + & + & + & + \\
$18 \mathrm{HN}$ & + & + & + & + & + & + & + & + & + & + \\
$19 \mathrm{HN}$ & + & + & + & + & + & + & + & + & + & + \\
$20 \mathrm{HN}$ & + & + & + & + & + & + & + & + & + & + \\
$21 \mathrm{HN}$ & + & + & + & + & + & + & + & + & + & + \\
$22 \mathrm{HP}$ & + & + & + & + & + & + & + & + & + & + \\
$23 \mathrm{HP}$ & + & + & + & + & + & + & + & + & + & + \\
$24 \mathrm{HP}$ & + & + & + & + & + & + & + & + & + & + \\
$25 \mathrm{HP}$ & + & + & + & + & + & + & + & + & + & + \\
$\mathrm{O} 395$ & + & + & - & + & - & + & - & + & + & + \\
\hline & & & & & & & & & & +
\end{tabular}

The immune hybrid results of Inaba antiserum with $\mathrm{O} 395$ and Ogawa antiserum with I389 did not appear $52 \mathrm{kDa}$,
$45 \mathrm{kDa}, 38 \mathrm{kDa}$, and $31 \mathrm{kDa}$ antigens. It can be explained that $\mathrm{I} 389$ did not have $52 \mathrm{kDa}$ antigen and $\mathrm{O} 395 \mathrm{did}$ not have $45 \mathrm{kDa}, 38 \mathrm{kDa}$ and $31 \mathrm{kDa}$ antigens. Thus, Inaba and Ogawa antiserums did not have corresponding antibodies to react to these antigens.

Table 3. The difference of the antigenic components of V.cholerae strains (using Ogawa antiserum in Western-blot)

\begin{tabular}{|c|c|c|c|c|c|c|c|c|}
\hline \multirow[t]{2}{*}{ Strains } & \multicolumn{8}{|c|}{ Antigens Size (kDa) } \\
\hline & 79 & 62 & 52 & 42 & 35 & 26 & 23 & 20 \\
\hline $\mathrm{O} 395$ & + & + & + & + & + & + & + & + \\
\hline $1 \mathrm{AG}$ & + & + & + & + & + & + & + & + \\
\hline $2 \mathrm{AG}$ & + & + & + & + & + & - & - & + \\
\hline $3 \mathrm{AG}$ & + & + & + & - & + & - & - & + \\
\hline $4 \mathrm{CM}$ & + & + & + & + & + & - & - & + \\
\hline $5 \mathrm{HN}$ & + & + & + & + & + & + & + & + \\
\hline $6 \mathrm{HN}$ & + & + & + & + & + & + & + & + \\
\hline $7 \mathrm{HN}$ & + & + & + & - & + & - & - & + \\
\hline $8 \mathrm{HN}$ & + & + & + & + & + & + & + & + \\
\hline $9 \mathrm{HN}$ & + & + & + & + & + & - & + & + \\
\hline $10 \mathrm{HN}$ & + & + & + & + & + & - & + & + \\
\hline $11 \mathrm{HP}$ & + & + & + & + & + & + & - & + \\
\hline $12 \mathrm{AG}$ & + & + & + & + & + & - & + & + \\
\hline $13 \mathrm{HP}$ & + & + & + & + & + & - & + & + \\
\hline $14 \mathrm{HP}$ & + & + & + & + & + & - & + & + \\
\hline $15 \mathrm{HN}$ & + & + & + & + & + & - & + & + \\
\hline $16 \mathrm{QN}$ & + & + & + & + & + & - & + & + \\
\hline $17 \mathrm{HN}$ & + & + & - & + & + & + & + & + \\
\hline $18 \mathrm{HN}$ & + & + & - & + & + & + & + & + \\
\hline $19 \mathrm{HN}$ & + & + & - & + & + & + & + & + \\
\hline $20 \mathrm{HN}$ & + & + & + & + & + & + & + & + \\
\hline $21 \mathrm{HN}$ & + & + & + & + & + & + & + & + \\
\hline 22HP & + & + & - & + & + & + & + & + \\
\hline $23 \mathrm{HP}$ & + & + & - & + & + & + & + & + \\
\hline 24HP & + & + & - & + & + & + & + & + \\
\hline $25 \mathrm{HP}$ & + & + & - & + & + & + & + & + \\
\hline I389 & + & + & - & + & + & + & + & + \\
\hline
\end{tabular}

Note: + yes; - no

As can be seen, the strains of $17 \mathrm{HN}, 18 \mathrm{HN}, 19 \mathrm{HN} 22 \mathrm{HP}$, 23HP, 24HP and 25HP (7/25 strains) contained antigens of $\mathrm{I} 389$ and $\mathrm{O} 395$ but $52 \mathrm{kDa}$ antigen did not appeared. So it could be confirmed that their antigenic components were identical to antigens of V.cholerae I389 serotype Inaba.

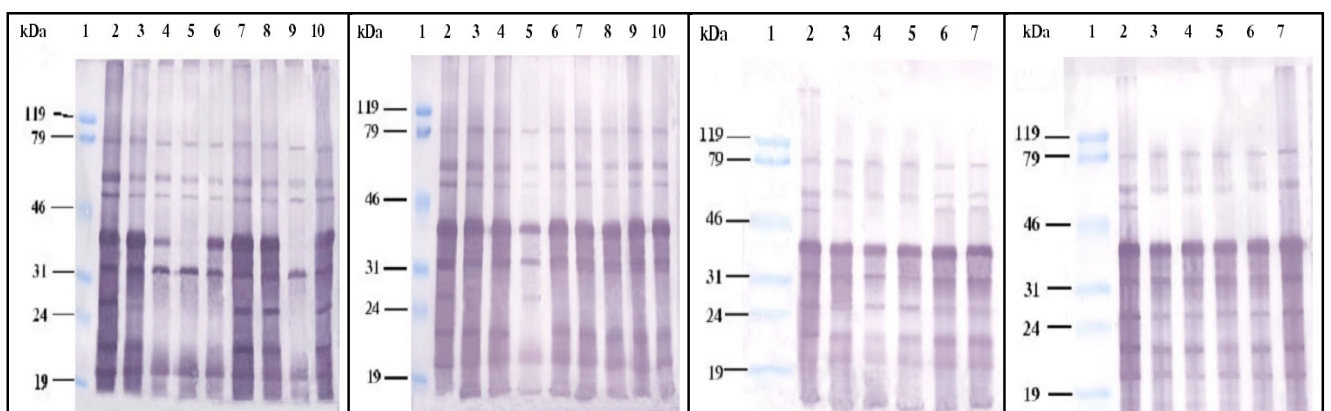

A
B

Figure 3. Western-blot of Ogawa antiserum and V.cholerae strains (see Table 1) (A) strains 1-8; (B) strains 9-16; (C) strains 17-21; (D) strains 22-25 and I389 (Protein markers: A1, B1, C1, D1; O395: A2, B2, C2, D2; I389: D7) 
The strains of $1 \mathrm{AG}, 5 \mathrm{HN}, 6 \mathrm{HN}, 8 \mathrm{HN}, 20 \mathrm{HN}$ and $21 \mathrm{HN}$ (6/25 strains) contained antigens of I389 and O395 including $52 \mathrm{kDa}$ antigen. This could happen due to serotype Inaba and serotype Ogawa can be transformed into each other easily, especially transformation from Ogawa to Inaba (Villeneuve S. et al., 2000; Kenneth Todar, 2002).

The remaining strains of $2 \mathrm{AG}, 3 \mathrm{AG}, 4 \mathrm{CM}, 7 \mathrm{HN}, 9 \mathrm{HN}$, $10 \mathrm{HN}, 11 \mathrm{HP}, 12 \mathrm{AG}, 13 \mathrm{HP}, 14 \mathrm{HP}, 15 \mathrm{HN}$ and $16 \mathrm{QN}$ (12/25 strains) had antigens that were not identical to standard strains; appearing $52 \mathrm{kDa}$ antigen of $\mathrm{O} 395$ but lacking some antigens of I389. So they were classified in a new group with changed antigenic components. However, the changes are just deficiency of antigens, not appearing new antigens.

Among 25 V.cholerae strains, there were 6 antigens in common including $79 \mathrm{kDa}, 62 \mathrm{kDa}, 45 \mathrm{kDa}, 35 \mathrm{kDa}, 31 \mathrm{kDa}$ and $20 \mathrm{kDa}$ antigens. $23 / 25$ strains had $42 \mathrm{kDa}$ antigen; $5 / 25$ strains contained $38 \mathrm{kDa}$ and $23 \mathrm{kDa}$ antigens and $11 / 25$ contained $26 \mathrm{kDa}$ antigen.

\section{Conclusion}

There were 11 different antigens including sizes of $79 \mathrm{kDa}, 62 \mathrm{kDa}, 52 \mathrm{kDa}, 45 \mathrm{kDa}, 42 \mathrm{kDa}, 38 \mathrm{kDa}, 35 \mathrm{kDa}$, $31 \mathrm{kDa}, 26 \mathrm{kDa}, 23 \mathrm{kDa}$ and $20 \mathrm{kDa}$. In which, antigens of $45 \mathrm{kDa}, 42 \mathrm{kDa}, 31 \mathrm{kDa}$ and $20 \mathrm{kDa}$ are similar to $\mathrm{OmpS}$, OmpT, Omp-31kDa and TcpA, and are considered as cholera vaccine-candidate antigens. Based on reported researches, we identified the antigenic components of V.cholerae strains in this research are the Out Membrane Proteins (Omp) and Toxin Coregulated-Pili A (TcpA).

There were 6 antigenic components in common among 25 strains including $79 \mathrm{kDa}, 62 \mathrm{kDa}, 45 \mathrm{kDa}, 35 \mathrm{kDa}, 31 \mathrm{kDa}$ and $20 \mathrm{kDa}$. $23 / 25$ strains contained $42 \mathrm{kDa}$ antigen; $5 / 25$ strains contained $38 \mathrm{kDa}$ and $23 \mathrm{kDa}$ antigens; $11 / 25$ strains contained $26 \mathrm{kDa}$ antigen.

Among 25 V.cholerae strains; 7/25 strains had antigens identical to V.cholerae I389 serotype Inaba; 6/25 strains contained antigens of I389 and O395; 12/25 strains had changes of antigenic components. The changes are lacking of antigens, not appearing new antigens.

\section{References}

[1] Asaduzzman M., Ryan E.T., John M., Hang L., Khan A.I., Faruque A.S.G., Taylor R.K., Calderwood S.B., Qadri F. 2004. The major subunit of the toxin coregulated pilus TcpA induces muscosal and systemic immunoglobulin A immune responses in pateints with cholera caused by Vibrio cholerae $\mathrm{O} 1$ and O139. Infection and Immunity, 72(8): 44484454.

[2] Du Yan, Jia Wen-xiang, Liu Li 2004. Toxincoregulated pilus-loaded microparticales as a vaccine against Vibrio cholerae O139. Chinese Medicine Journal, 117(4): 618-620.

[3] Forrest B.D. 1992. Indirect measurement of intestinal immune responses to an orally administered attenuated baterial vaccine. Infection and Immunity, 60(5): 2023-2029.

[4] Kenneth Todar 2002. Vibrio cholerae and Asiatic Cholera, Todar's Online Texbook of Bacteriology.

[5] Kumar S., Ray P., Singh H., Kumar Ganguly N. 2001. Immunogenicity and protective role of an IgA reaction 31-kDa antigen of Vibrio cholerae 0139. Journal of Medical Microbiology, 50: 489-498.

[6] Richardson K., Kaper J.B., Levine M.M. 1989. Human immune response to Vibrio cholerae $\mathrm{O} 1$ whole cells and isolated outer membrane antigens. Infection and Immunity, 57(2): 495-501.

[7] Sahu G.K., Chowdhury R., Das J. 1994. Heat shock response and heat shock protein antigens of Vibrio cholerae. Infection and Immunity, 62(12): 56245631.

[8] Simonet V.C., Basle A., Klose K.E, Delcour A.H. 2003. The Vibrio cholerae porin OmpU and OmpT Have Distinct Channel Properties. Journal of Biological Chemistry, 278(19): 17539-17545.

[9] Sperandio V., Giron J.A., Silveira W.D., Kaper J.B. 1995. The OmpU Outer Membrane protein, a Potential Adherence Factor of Vibrio cholerae. Infection and Immunity, 63(11): 4433-4438.

[10] Stewart-Tull D.E., Bleakley C.R., Galloway T.S. 2004. Characteristics of Vibrio cholerae proteinases: potential, candidate vaccine antigens. Vaccine, 22(23-24): 3026-3034.

[11] Tacket C.O., Taylor R.K., Losonsky G. 1998. Investigation of roles of toxin-corregulated pili and manose-sensitive hemagglutinin pili in the pathogenesis of Vibrio cholerae $\mathrm{O} 139$ infection. Infection and Immunity, 66(2): 692-695.

[12] Taylor D.N., Cardenas V., Perez J. 2000. Safety, immunogenicity, and lot stability of the whole cell/recombinant B subunit (WC/rCTB) cholera vaccine in Peruvian adults and children. American Journal of Tropical Medicine and Hygiene, 61(6): 869-873.

[13] Villeneuve S, Boutonnier A, Mulard L.A, Fournier J.M 2000. Immunochemical characterization of an Ogawa-Inaba common antigenic determinant of $\mathrm{Vib}$ rio cholerae O1. Microbiology, 145(9): 2477-2484. 